\title{
Public knowledge about hepatitis B-related issues in Korea
}

\author{
C CHRUSCH MD, GY MINUK MD FRCPC
}

C CHRUSCH, GY MINUK. Public knowledge about hepatitis B-related issues in Korea. Can J Infect Dis 1996;7(1):53-55. Hepatitis B infection is endemic in many parts of the world, including Korea. Basic knowledge of the hepatitis B virus by the public is a prerequisite for the development of a successful vaccination program. A survey was conducted in rural Korea to examine public knowledge of hepatitis B etiology, symptoms, transmission, risk factors and prevention. It was found that knowledge independently correlated with education and female sex, but that overall knowledge of hepatitis B was poor. The preferred information sources in order of preference were physicians, television and public health nurses. This information may be useful in designing public health education and vaccination programs in developing populations.

Key Words: Hepatitis, Hepatitis B virus, Korea, Liver, Vaccine

\section{Sensibilisation du grand public à l'hépatite B en Corée}

RÉSUMÉ : L'hépatite B est endémique dans plusieurs régions du monde, y compris en Corée. Pour assurer le succès d'un programme de vaccination, il est nécessaire d'informer le public sur le virus de l'hépatite B. Un sondage a été effectué dans les régions rurales de la Corée afin de mesurer le degré de connaissance du public au sujet de l'hépatite B, de son étiologie, de ses symptômes, des voies de transmissions, des facteurs de risque et de la prévention. Ce sondage a établi une corrélation indépendante entre le degré de connaissance et le degré d'éducation et le fait d'être de sexe féminin, mais a révélé que l'hépatite $B$ était mal connue. Les sources d'information privilégiées par ordre de préférence étaient : les médecins, la télévision et les infirmières en santé publique. Cette information peut être utile pour la création de matériel éducatif et de programmes de vaccination à l'intention du public dans les pays en voie de développement.

$\mathrm{H}$ epatitis B virus (HBV) infection is endemic in many parts of the world (1). Infection with this virus is important because $90 \%$ of newborns and $5 \%$ to $10 \%$ of adults become chronic carriers following exposure, and the sequelae of the carrier state may include chronic active hepatitis, cirrhosis and hepatocellular carcinoma (2-4). Currently, the majority of these problems cannot be treated effectively.

While HBV infection may not be treatable, it is preventable (5-7). A safe and effective vaccine has been available since 1982. Although there are various vaccination dosages and schedules, they all require three separate inoculations, usually at zero, one and six months (7). It is important to note that the success of these vaccination programs depends in part on the cooperation of the target population to return twice at specific times to complete the vaccination series. Public health education may be the most important mechanism to maximize such participation in a vaccination program.

The prevalence of hepatitis B surface antigen (HBsAg) positivity, indicating infection with HBV, in Korea is high, ranging from $7 \%$ to $14 \%$ depending on the assay method used (8). In

Departments of Medicine and Pharmacology, and Liver Diseases Unit, University of Manitoba, Winnipeg, Manitoba Correspondence and reprints: Dr C Chrusch, Department of Medicine, Health Sciences Centre, 820 Sherbrook Street, Winnipeg, Manitoba R3A 1R9. Telephone 204-787-4662, fax 204-775-4255

Received for publication April 6, 1995. Accepted July 12, 1995 
TABLE 1

Distribution of Kanghwa, Korea survey population by sex and age

\begin{tabular}{cccc}
\hline Age (years) & Male (\%) & Female (\%) & Total $(\%)$ \\
\hline $10-19$ & $6.8(4)$ & $4.8(3)$ & $5.7(7)$ \\
$20-29$ & $20.3(12)$ & $19.0(12)$ & $19.7(24)$ \\
$30-39$ & $20.3(12)$ & $22.2(14)$ & $21.3(26)$ \\
$40-49$ & $15.3(9)$ & $22.2(14)$ & $18.9(23)$ \\
$50-59$ & $28.8(17)$ & $19.0(12)$ & $23.8(29)$ \\
$60-69$ & $3.4(2)$ & $11.1(7)$ & $7.4(9)$ \\
$\geq 70$ & $5.1(3)$ & $1.6(1)$ & $3.3(4)$ \\
\hline
\end{tabular}

Kanghwa, Korea, the location of the present study, the prevalence of HBsAg positivity as measured by radioimmunoassay is $12 \%$, with $40 \%$ to $60 \%$ of individuals having serological evidence of previous HBV exposure (9).

In 1983 the Korean Ministry of Health and Social Affairs developed a five-year plan, covering the years 1984 to 1988 , for the prevention of hepatitis $B$. The target population amounted to 17.2 million persons. It included infants and primary school children, prostitutes, health care workers, patients receiving blood products, intravenous drug abusers, family contacts of hepatitis B patients and individuals living in groups, such as soldiers. As of June 1987, 4.8 million people had been immunized.

To determine what forms of public education would maximize population participation in a vaccination program, we surveyed rural residents in Kanghwa to assess public knowledge of hepatitis B and the residents' attitudes towards immunization.

\section{METHODS}

Kanghwa county is a rural area $58 \mathrm{~km}$ west of Seoul, Korea. The population in 1987 was 78,594 with $70 \%$ engaged in farming. The standard of living in the area is often poor, with some households not having plumbing and using coal for heating and cooking.

Free immunization against HBV infection for neonates was introduced in May 1985. All others wishing to receive vaccine must pay for it. For adults immunization at a health centre or subcentre costs $\mathrm{W} 6200$ or $\$ 11$ per immunization $(\mathrm{W} 560=\$ 1$ Canadian) or $\$ 33$ for the complete series. The charge for children is $\$ 5.54$ each, for a total of $\$ 16$. If vaccinated at a hospital or private clinic, adults would pay a total of $\$ 64$ and children a total of between $\$ 32$ and $\$ 42$. Anyone 10 years of age or older has serology for HBsAg done before immunization.

One hundred and twenty-two residents from four different municipalities of Kanghwa county were interviewed by senior medical students in March 1989. Interviewees were selected randomly during home visits through the area. No incentive for participation in the survey was offered. Five per cent of people approached refused to participate in the survey. The survey collected demographic information (age, sex, education, occupation, average income), asked questions related to
TABLE 2

Knowledge scores of the Kanghwa, Korea survey population

\begin{tabular}{llc}
\hline Topic & Scoring & Percentage \\
\hline Etiology & $2=$ Virus & $6.6(8)$ \\
& $1=$ Bacteria & $3.3(4)$ \\
Transmission & $2=$ Blood/sexual contact & $2.5(3)$ \\
& $1=$ Close person/person, oral & $27.9(34)$ \\
Risk & $2=$ Infant HBsAg+ mother, & $0.8(1)$ \\
& $\quad$ blood/sexual/family contact & \\
Symptoms & $2=$ Jaundice & $9.8(12)$ \\
& $1=$ Fatigue, malaise, nausea, & $15.6(19)$ \\
& $\quad$ vomiting, fever, abdominal & \\
Oncogenicity & $2=$ Hepatoma \\
Prevention & $2=$ Vaccine & \\
& $1=$ Condom, avoidance & $41.1(38)$ \\
\end{tabular}

HBsAg+ Hepatitis B surface antigen positive

the etiology, transmission, risk factors, symptoms, oncogenicity and the prevention of hepatitis B, and polled attitudes towards vaccination against $\mathrm{HBV}$ infection.

The survey data were analyzed by one-way ANOVA and multiple regression with SPSS (Statistical Package for the Social Sciences, SPSS Incorporated, Illinois).

\section{RESULTS}

The age and sex distribution of the surveyed population is shown in Table 1 . The mean \pm SD age was $41.3 \pm 14.7$ years, range 11 to 77 years. Forty-eight per cent of the population was male. Eighty-one per cent of the surveyed population replied that they had heard of hepatitis B, with their reported primary sources of information being television (58.2\%), a physician (16.4\%), or a friend or neighbour (13.9\%).

Knowledge of hepatitis B was assessed by six questions about etiology, transmission, risk factors, symptoms, oncogenicity and prevention. Open questions were used in preference to multiple choice to eliminate the possibility of a correct answer by chance. The questions were scored as shown in Table 2. For example, the answer 'bacteria' in the etiology question, although incorrect, was awarded one point since it implies that an infectious agent is the cause of hepatitis B. In regard to the symptoms of HBV infection, answers such as fatigue, malaise, nausea, vomiting, fever, abdominal pain and anorexia are correct, but were awarded only one point because they are nonspecific. The score for each question was added together to yield a total knowledge score as shown in Table 3 . The mean \pm SD knowledge score was $2.5 \pm 2.5$ points.

One-way ANOVA demonstrated that there was no association between occupation and knowledge of hepatitis $\mathrm{B}$ $(\mathrm{F}=2.17, \mathrm{P}=0.08)$. Multiple regression was used to determine which, if any, variables were associated with knowledge. The variables with a positive association with knowledge were female sex and education $(\mathrm{P}=0.01)$.

Eighty-three per cent of the surveyed population reported that they had heard of a vaccine for hepatitis B and $81 \%$ reported that they heard of hepatitis B. The most common 
source of this information was a physician $(27.0 \%)$ or television $(22.1 \%)$. Forty-six per cent of the surveyed population knew that the vaccine was a means of preventing hepatitis $B$ and $45 \%$ knew that three doses of vaccine are needed.

The survey population preferred to receive vaccination from a physician $(64.8 \%)$ or a public health nurse $(28.7 \%)$ at a hospital (45.9\%), a health centre or health subcentre $(50.9 \%)$.

The preferred methods of receiving health information are from a physician (45.1\%), television $(23.8 \%)$ or a public health nurse (18.9\%).

\section{DISCUSSION}

The results of this study reveal that sex and education are independently related to knowledge about HBV infection. It is not surprising that knowledge about hepatitis B is associated with education, but why it was associated with female sex is unclear. Perhaps females have had more exposure to the methods that have been used to disseminate health information. For example, in Korea they are more likely to care for children and the ill and therefore have more contact with the village health worker, who makes home visits to enhance health consciousness and to perform follow-up care and case finding. Moreover, as women are responsible for the health of the family, particularly that of the children, there is a perceived need for them to learn more about hepatitis B vaccine in particular and about health in general.

The results of this study also suggest that public health education about hepatitis B is incomplete and perhaps misdirected in this population. Public health education appears to have focused on vaccination, but has provided relatively less education about other aspects of the disease. The survey population was aware of a vaccine but not of the etiology, transmission, risk factors or symptoms of hepatitis. The ma-

ACKNOWLEDGEMENTS: This work was supported by grants from the Canadian Public Health Association, the Canadian Society for Tropical Medicine and International Health, and the Faculty of Medicine, University of Manitoba, Winnipeg. The authors acknowledge the assistance of the staff at Yonsei University in carrying out this study and Ms D Byron for her prompt and accurate typing of the manuscript.

\section{REFERENCES}

1. Jiang Y. Epidemiological studies of viral hepatitis A and B in the Peoples' Republic of China. In: Szmuness W, Alter HJ, Maynard JE, eds. Viral Hepatitis: 1981 International Symposium. Philadelphia: The Franklin Institute Press, 1982:121-8.

2. Beasley RP, Lin CC, Hwang LY, Chien CS. Risk of hepatocellular carcinoma in hepatitis B virus infections: a prospective study in Taiwan. In: Szmuness W, Alter HJ, Maynard JE, eds. Viral Hepatitis: 1981 International Symposium. Philadelphia: The Franklin Institute Press, 1982:261-72.

3. Beasley RP, Hwang LY, Lin CC, Chien CS. Hepatocellular
TABLE 3

Total knowledge scores of the Kanghwa, Korea survey population

\begin{tabular}{ccc}
\hline $\begin{array}{c}\text { Total knowledge } \\
\text { score }\end{array}$ & Frequency & Percentage \\
\hline 0 & 45 & 36.9 \\
$1-3$ & 35 & 28.7 \\
$4-6$ & 35 & 28.7 \\
$7-9$ & 5 & 4.1 \\
$10-12$ & 2 & 1.6 \\
Total & 122 & 100.0 \\
\hline
\end{tabular}

jority of the surveyed population (83\%) replied that they had heard of a vaccine for hepatitis B but only $46 \%$ answered that the vaccine was a means for preventing HBV infection. Thus, they know the vaccine exists, but do not understand what it is for.

The preferred methods for obtaining health care information were from a doctor, public health nurse or television, indicating a preference for receiving information directly from a health care professional. Emphasizing the importance of hepatitis B to the village health worker may be one way to improve public knowledge. Since the information would be passed on in conversation, a lack of literacy and televisions would not necessarily be obstacles to education about hepatitis B.

In summary, this study was a demonstration of a simple and inexpensive method for gathering information that may be useful in the design of an effective public health education and vaccination program for developing populations.

carcinoma and hepatitis B virus: A prospective study of 22,707 men in Taiwan. Lancet 1981;ii:1129-33.

4. Chung WK, Sun HS, Park DH, Minuk GY, Hoofnagle JH. Primary hepatocellular carcinoma and hepatitis B virus infection in Korea. J Med Virol 1983;11:99-104.

5. Purcell RH, Gerin JL. Hepatitis B vaccine: on the threshold. Am J Clin Pathol 1978;70(Suppl):159-69.

6. Hilleman MR, Buynak EB, McAleer WJ, McLean AA, Provost PJ, Tytell AA. Hepatitis A and hepatitis B vaccines. In: Szmuness W, Alter H, Maynard J, eds. Viral Hepatitis: 1981 International Symposium. Philadelphia: Franklin Institute Press, 1982:385-97.

7. Immunization Practices Advisory Committee. Update on hepatitis B prevention. MMWR 1987;36:353-66.

8. Sun HS. Prevalence and characteristics of HBV infection in Korea. Proceedings of Asian Symposium on Strategies for Large Scale Hepatitis B Immunization. Hong Kong: Science Press, 1986:55-61.

9. Kim IS, Oh HC, Kim SD, Lee WY. Prevalence and changes of HBsAg and anti-HBs for a one year period in natural status and after hepatitis B vaccination. Korean J Epidemiol 1987;9:40-8. 


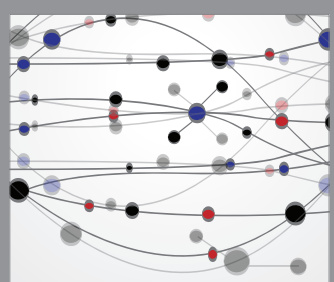

The Scientific World Journal
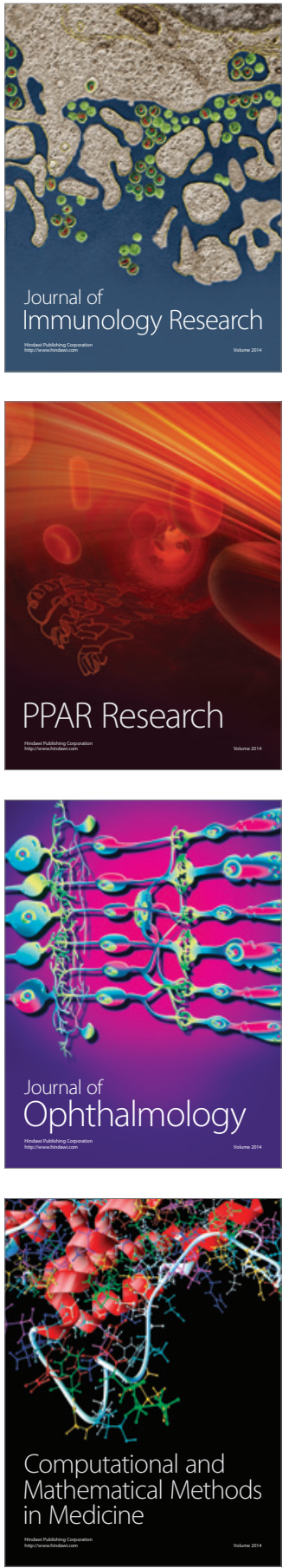

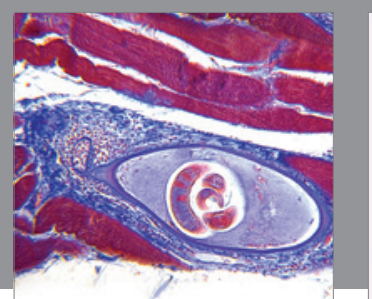

Gastroenterology Research and Practice

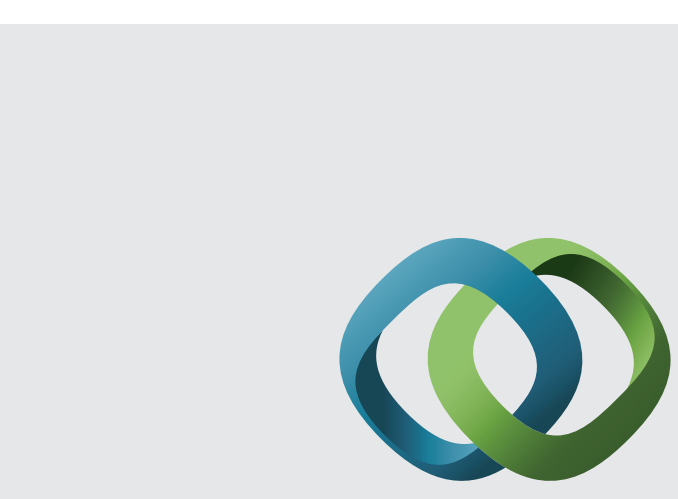

\section{Hindawi}

Submit your manuscripts at

http://www.hindawi.com
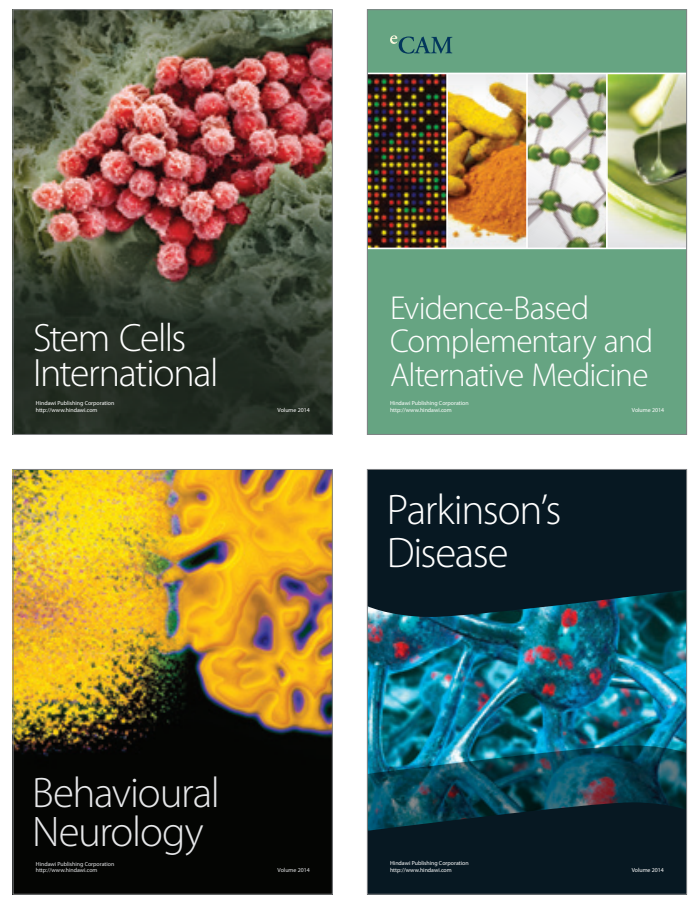
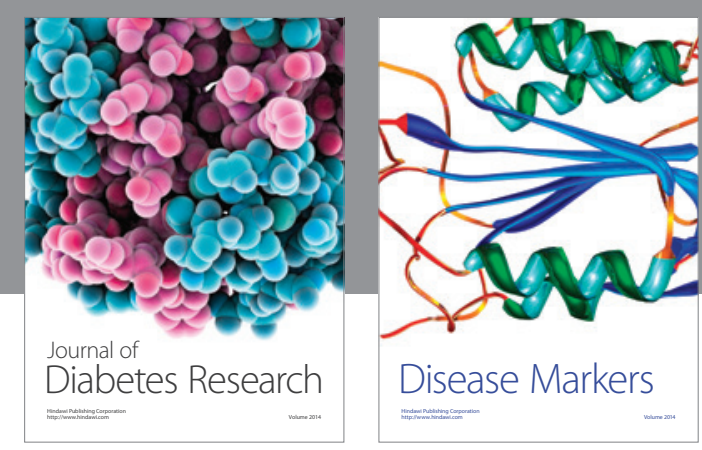

Disease Markers
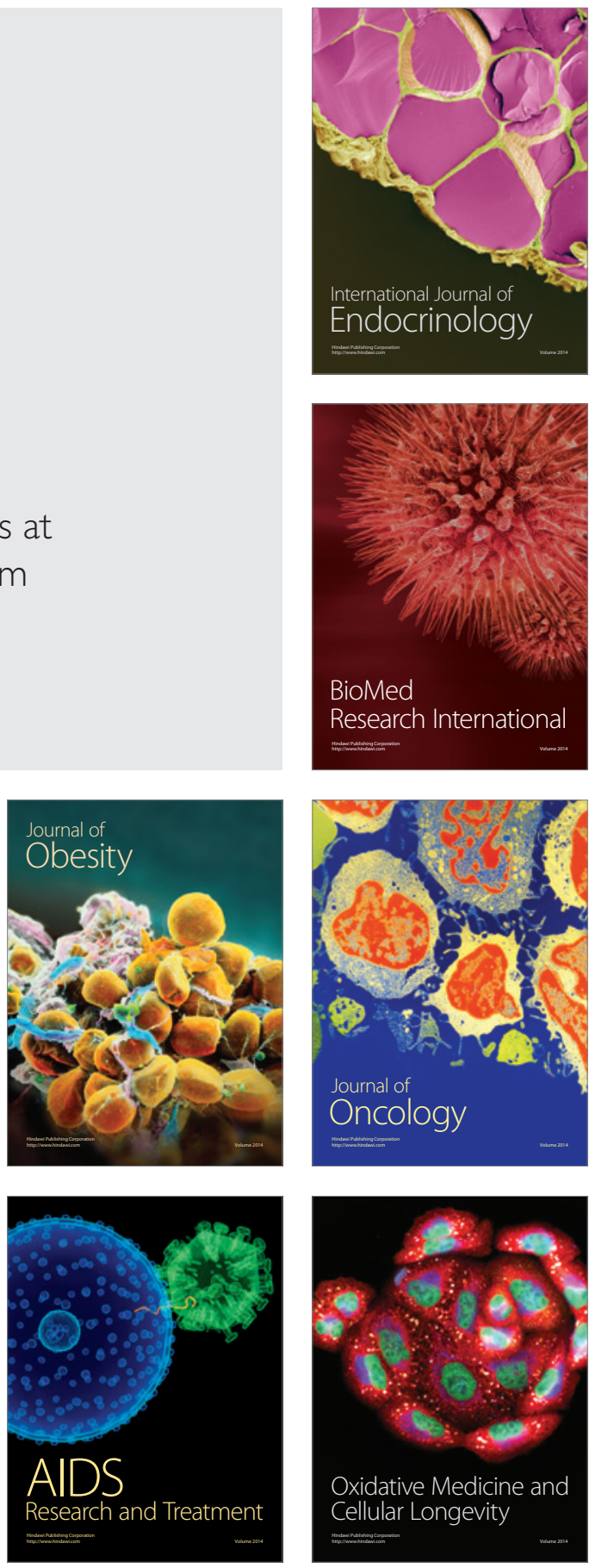